\title{
Refugees, UNHCR and Human Rights: Current Dilemmas of Conflicting Mandates
}

\author{
Daniel Warner
}

\begin{abstract}
There continues to be an increase in concern for human rights in different areas, and refugees are no exception. Specifically, UNHCR has become more concerned with human rights issues. This article reviews the standard phrases used to indicate the relationship between $h u$ man rights and refugees before examining the specificity of refugees in terms of human rights. The point of view taken is that the specificity of the refugee situation is different from nomal human rights concerms, and the conclusion is that including refugees within a human rights framework may actually weaken refugee protection. Thiat is, we propose that although human rights in and of themselves cannot beargued against, the inclusion of refugees within a human rights régime may actually weaken the kinds of protection necessary for refugees and their particular situation. UNHCR would do well to focus on its limited mandate rather than including refugees within the human rights regime.
\end{abstract}

\section{Precis}

L'inquiétude pour le respect des droits humains dans differentes zones continue d'augmenter, et les réfugiés ne font pas exception. Plus spécifiquement le Haut Commissariat des Nations Unies pour les réfugiés (HCR) se soucie de plus en plus des questions dedroits humains. Le present article passe en reoueles formulations usuelles utilisées pour indiquer la relation entre droits humains et refuge, puis examine la spécificité de la question des réfugiés en terme de droits humains. Le point de oue adopté est celui selon

Daniel Warner, Ph.D., is Professor and Director, Institut Universitaire de Hautes Études Intermationales, Genzoe, Suisse.

$A$ version of this article was presented at the University of Nebraska, Lincoln, and at Harvard University Law School. lequel la spécificité de la situation des réfugiés est différente des problèmes habituels de droits humains. La conclusion est que l'inclusion de la question des réfugiés dans un dispositifformulé en termes de droits humains risque d'affaiblir la protection des réfugiés dans les faits. Ainsi, nous proposons que, en dépit du fait que les droits humains en soi et par eux mêmes ne peuvent pas faire l'objet de la moindre objection, l'inclusion du refuge dans le cadre d'un régime des droits humains risque d'affaiblir de facto les types de protections particulières requises pour les réfugiés dans leurs situations spécifiques. Le HCR ferait biende concentrer son attention sur son mandat étroit, plutôt que de se lancer dans l'aventure d'une inclusion du refuge sous le régime des droits humains.

In spite of the fact that many efforts have been and are being made to show the complementarity of human rights and refugee protection, ${ }^{1}$ I would like to develop an alternate position to indicate whereIbelieve there are major problems in their relationship. The reason for this analysis is that I believe that imprecise conceptual frameworks lead to imprecise operational mandates that can cause serious confusion on the ground. In the last 7 years, the United Nations High Commissioner for Refugees (UNHCR) has had enormous success in terms of expansion of budget and mandate. It is now the time to re-examine many of the activities of UNHCR, and the relationship between human rights, refugees and UNHCR is a most appropriate venue for one aspect of that exercise.

My argument will be in three parts. First, I would like to briefly mention the standard phrases used to indicate the relationship between refugees and human rights. Then, I would like to analyze those phrases to show where and why they are mistaken. Finally, based on that analysis, I will offer a different line of reasoning and develop its operational implications.

The core international instrument describing the rights of refugees, the 1951 Convention Relating to the Status of Refugees, says in its first preambular paragraph that it is derived from the UN Charter and the Universal Declaration. Article 14 of the Universal Declaration of Human Rights says that: "Everyone has the right to seek and to enjoy in other countries asylum from persecution." That is the basic human right central to the refugee régime. One can thus easily establish a hierarchy with the UNCharter and Universal Declaration as the overarching structures within which the refugee régime exists. That is, within the general framework of the UNCharter and the Universal Declaration refugees are specifically referred to in Article 14 of the Declaration and the 1951 Convention.

More specifically, in a recent internal policy paper by UNHCR, it was noted that: "Refugees are, by detention, victims of human rights violations." 2 The paper went on to say that: "UNHCR, as the principal UN agency which is tasked with providing protection to refugees, has a globalmandate to ensure that the human rights of this distinct group of beneficiaries are upheld. " ${ }^{3}$ The basic policy consideration of this analysis is that protection work for refugees is in essence human rights work on behalf of a specific category. This position is consistent with the hierarchy mentioned above in that refugee protection is within the human rights domain but targeted to a specific group.

In a speech to a recent Executive Committee meeting of UNHCR, the UNHigh Commissioner for Human Rights, Mary Robinson, confirmed this hierarchy when she said that

Human rights are deeply connected to the problem of refugees: first and 
foremost because human rights violations often represent the root causes of refugee flows and, secondly, because the problem of refugees can be properly managed and effectively solved only through an improvement in the standards of protection of human rights. In this regard, I completely share the High Commissioner's opinion that refugee protection should be considered within the broader framework of international human rights. ${ }^{4}$

What does this all mean? Beside the obvious hierarchical positioning, what is the exact nature of the relationship? The refugee is a specific category of people within the global consideration of human rights. That is, since human rights applies to all people, refugees, as people, areobviously covered by human rights norms. That much is obvious. Next, since refugees are victims of human rights abuses, they merit special attention in different situations along the humanitarian continuum: averting refugee flows, allowing people the right to flee or seek asylum from persecution, guaranteeing rights in camps, and helping return to home, integrating into the country of asylum, or resettling in a third country. That much is clear from Mrs. Robinson's comment.

All this is well and good and sounds just fine, but it lacks a clear level-ofanalysis basis. The major problem is the incapacity of the two High Commissioners to define the situation of the refugee, to understand the specificity of the refugee behind the legalism of the refugee definition and broad generalizations about human rights leading to calls for cooperation. What happens along the humanitarian continuum to make the refugee a specific category? From the High Commissioner for $\mathrm{Hu}$ man Rights perspective, this lack of clarity is politically understandable-after all, one does not want to exclude a given category of persons from under her umbrella because of overly specific categorization. From UNHCR's perspective, by contrast, this lack of clarity is dangerous because it weakens the very focus of what the organization is supposed to bedoing. As with many things goingonat UNHCR today, the origind mandate continues to be watered down with refugees the unwitting victims. The danger we are calling attention to is that the lack of clarity by UNHCR in its relationship to human rights threatens its operational effectiveness.

What is the nature of the level-ofanalysis problem that worries us? The problem is locating the refugee within a specific set of circumstances located within time and place. In essence, the problem is the lack of focus by UNHCR on the "refugeeness" (specificity) of the refugee.Temporally, refugees havebeen the victims of an upheaval. The cause of refugee flows is not just any human rights abuse, it is a fundamental suspension of accepted practice. In this sense, the refugee is in between the normal functioning of society and a new, stable situation, whether it be once the conflict in country of origin has settled down, or somewhere else where settlementin dignity can be assured. The refugee represents a significant temporal rift, 5 a radical discontinuity with the past. All people are of concern to the human rights régime, refugees are in a legal limbo. Refugees are neither members of a stable, original community nor are they stable members of a new community.

And, because the refugee is a victim of this radical discontinuity and in limbo, the refugee has the spatial problem of finding a place and legal protection because of the upheaval and uprooting. The refugee needs both physical and legal protection from the given situation. In this sense, UNHCR and its protection régime takes the place of a government during the temporal rift until a specific place is found wherein there is a direct relationship between the place the refugee resides and the government responsible for that people and territory. Being in refugee camps, in this sense, is a form of suspended animation. Refugees in camps remain in protection orbit until they are resettled and some government takes responsibility for them from UNHCR.

There is a difference between a normative system of protection and instrumentality. Special circumstances call for diferent instumesitality. While most regimes are state-centric and only indirectly international, the mandate of UNHCR is directly international. UNHCR becomes responsible for the protection of people in given situations without the consent of a government. That is the consequence of the specificity of the refugee situation and what makes refugees different from other vulnerable groups.

How does this description of the "refugeeness" of the refugee situation clash with the human rights régime? Human rights treaties are standard setting instruments. They carry a set of prescriptions abouthow people should be treated, with what rights individuals are endowed. While one could argue that the weakness of this régime is the lack of clear obligations on states to ensure that individuals are guaranteed those rights, there is no question that states have the primary obligation under the human rights regime. Also, human rights standards are general norms that codify certain rights that are to be actualized in the lives of all peoples. In sum, human rights are standards meant to codify what should happen in a functioning society where the government is responsible for its activities in terms of its citizens.

Refugees are a specific category of people because the very situation they find themselves in is the result and continuation of dysfunctional politics. Not only are refugees victims of human rights abuses, they are victims of the inability of a government to protect them, in themostbasic sense of the term, because the normal legal framework that guarantees protection is not functioning. In another context, and to argue by analogy, humanitarian law deals withnorms during conflict-that which is essentially the antithesis of a legal framework. Humanitarian law establishes a legal framework within a situation that is basically illegal, or a second order of legality. ${ }^{6}$

The refugee régime is meant to establish rules of conduct for people in an analogous situation, where the normal laws have broken down. Refugee law protects those who are outside a func- 
tioning system just as humanitarian law establishes rules of conduct during war. Both humanitarian law and refugee law deal with abnormal situations where normal international rules are necessary but not sufficient to deal with the inability of the local government to function effectively. ${ }^{7}$ In humanitarian and refugee law, specific organizations are designated to oversee the functioning of the treaties dealing with specific situations, whereas in human rights law the government of the country itself is ultimately responsible. In this sense, the International Conflict Resolution Centre (ICRC) and UNHCR have different mandates than the High Commissioner for Human Rights.

In sum, the human rights regime sets standards, but is not meant to deal with situations in which those standards break down. The refugee is not just a specific category within the human rights regime; the refugee represents a specific situation which is outside the standard human rights framework. This is why whereas human rights norms are meant to be implemented by governments, refugee law is sometimes carried out by UNHCR in the absence of or even contrary to governments. Refugee law can function in failed states.

To include the refugee regime within global human rights is to weaken the specificity of the refugee situation and to deny the difference between the source of normative protection and the instrumentality of that protection. By moving the refugee mandate closer to human rights, just as would be moving the humanitarian mandate closer to human rights, one denies the power of the particularity of those victims and their needs in particular situations. Refugees need special help in situations where governments are no longer able or willing to ensure that human rights norms are effective. The entire refugee régime is an edifice carefully constructed in situations when the human rights regime has broken down. While it is obvious that the breakdown of the system and the victims are somehow connected, the refugee régime was constructed to deal with the victims of the temporal/spatial breakdown, some- thing the human rights régime does notdo.

By moving the refugee regime closer to human rights and searching for complementarity, the UN High Commissioner for Refugees is running the risk that refugees will become another category of human rights abuses, like children and women, and that its own role will be diminished. While it may be tempting to UNHCR officials to draw closer to the human rights regime for various political reasons, it is insufficient to render service to the specificity of the refugee situation we have described. The upheaval and uprooting that causes refugees and inhibits their return in dignity is much deeper and complex than merely speaking of human rights abuses. Yes, refugees are a category within human rights, and certainly the human rights regime should apply to refugees. While UNHCR says that it wishes to distance itself from certain aspects of human rights monitoring because of fear of becoming too political, ${ }^{8}$ the problem with incorporating refugees too closely to the human rights regime is that politically it will weaken UNHCR and theneeds for refugeeprotection.

In other words, our perspective is that while the entire spectrum of humanitarian assistance must be considered, from preventive diplomacy and early warning to reconstructing war-torn societies, it should only be considered in terms of protecting people when thinking of refugees. When UNHCR began to deal with early warning and preventive diplomacy-moving it closer to the human rights regime-itmoved away from protecting individuals who were victims. Obviously, preventive diplomacy serves to avert victims. But, UNHCR was designed to deal with a special category of people within a special situation, not the special situation itself. By looking at the spectrum of the situation from preventive diplomacy to rebuilding war-torn societies, UNHCR has lost its vision of its original mandate and risks losing its specificity and effectiveness.

Why has the ICRC maintained the specificity of its mandate in time and place? It has done so because it recognizes that the laws of war deal with a very limited and limiting situation. UNHCR has gotten away from its mandate of protection of refugees in a way that can easily lead to confusion of mandates with other organizations. While it has been tempting for UNHCR to become the lead agency in different situations, such as the Former Yugoslavia, ${ }^{9}$ this pattern has been at an enormous cost to the organization and those it is supposed to serve. Now that the expanded mandates are being reduced, there is growing fear at UNHCR that the heart and soul of the organizationprotection-has been lost.

UNHCR is going through a serious organizational downsizing. No one imagines that it will ever return to its budget and size of the early 1990s. What is unfortunate is that because it has spread itself so thin, the downsizing goes across the board and will affect its protection mandate, which has already been weakened. If the downsizing were to affect those areas added on to protection there would less worry.

Our final point, therefore, is that UNHCR must re-examine its priorities and return to the very simple, butdaunting task, of protecting refugees. While this may not seem current or particularly ambitious-indeed, there is a certain protection fatigue within the organization (after all, one does not want to seem to be doing the same thing over and over again)-this must be measured against the bureaucratic overstretch that went on in the absence of any organizational threat in the early 1990s. UNHCR had its moment in the sun, and perhapsnow it is becoming the victim of its own success. An organization that cannot say no to very different mandates will inevitably overstep its bounds. Thenew Emergency Relief Coordinator will certainly try to limit UNHCR's range of actions in an attempt to establish clear guidelines for hiumanitarian assistance. For if anyone understands the dangers of overlapping mandates and UNHCR overreach, it is Sergio De Mello, former Assistant High Commissioner for Refugees. 
But the question will remain as to the relationship between human rights and refugee protection and UNHCR. The resolution of that situation is not limited to operational activities. Indeed, the message should be coming from Mrs. Ogata that her priorities are clear and to the point. Without that voice-which has not been clearly articulated-we will continue to hear speeches about coordination from numerous High Commissioners, and to little avail. The UN system is bogged down in coordination problems. The reason for this is that agencies like UNHCR refuse to specify clear objectives and limit themselves to those objectives. And the end result is that the victims of abuses, in this case refugees, become caught up in a web of political overreach and endless calls for coordination. A little self-discipline on the part of the organizations will go a long way to clarifying mandates and helping those in need, which is, after all, the primary purpose of the organizations.

\section{Notes}

1. Human Rights and Humanitarian Law: The Quest for Universality, edited by Daniel Warner (The Hague/Boston/London: Martinus Nijhoff Publishers, 1997), where it was attempted to show certain com- monality among the human rights, humanitarian and refugee régimes in the name of overall individual protection. Another example to show complementarity would be Erica Feller, "UNHCR and Human Rights," Osterreichische aussenlpolitische Dokumentation, Special Issue 40th International Seminar for Diplomats 28th July-1st August 1997, 201-5. This current paper tries to suggest the limits of that cooperation and complementarity as it applies to the refugee régime.

2. "UNHCR and Human Rights: Policy Considerations and Proposals," UNHCR document, 1 and 4

3. Ibid., 5.

4. Statement by Mrs. Mary Robinson, UN High Commissioner for Human Rights, before the Executive Committee of UNHCR, 14 October 1997, 1.

5. For a more complete discussion of what $I$ mean by rifts here, see Daniel Warner, "Voluntary Repatriation and the Meaning of Return to Home: A Critique of Liberal Mathematics," Journal of Refugee Studies 7, no. $2 / 3$ (1994): 160-74.

6. See for example, Dietrich Schindler, "Le Comite international dela Croix-Rouge t les droit del'homme," Revue Internationale de La Croix Rouge (Janvier-Fevrier 1979): 315; Maurice Aubert, "De la Declaration des droits de l'homme et du citoyen du 26 août 1789 au droit international humanitaire actuel," Revue Internationale de La Croix-Rouge (Juillet-Août 1989): 112; Louise DoswaldBeck, Sylvain Vite, "Le droit international humanitaire et le droit des droit del'homme," ReoueInternationale de La Croix Rouge (Mars-Avril 1993): 99 128; Rapport Final du Groupe d'Experts sur les Droits de l'Homme adopté par la Commission sur la Croix-Rouge, le Croissant Rouge et la Paix, à sa XXVle Session, Avril 1989.

7. As Professor Schindler notes, "... the humanitarian treaties relevant in cases of armed conflict contain dispositions for individual protection more extended and more precise than the human rights treaties." Schindler, Reoue Internationale, op. cit., 11. Schindler, for various reasons, argues for a distinct separation between the tworégimes.

8. The dichotomy between political and humanitarian is as fraudulent as the one between practitioners and academics.

9. For recentcriticisms of this role, seeMichael Barutciski, "The Reinforcement of NonAdmission Policies and the Subversion of UNHCR: Displacement and Internal Assistance in Bosnia-Herzegovina (19921994)," International Journal of Refugee Law 8, no.1/2 (1996): 49-110; Alex Cunliffe, "AMandate too Far? The UNHCR as Lead Agency in the Former Yugoslavia," paper presented at the conference on Refugee Rights and Realities, University of Nottingham, 30 November 1996; Erin D. Mooney, "UNHCR and the Shifting Paradigm of Protection," paper presented at the conference on Refugee Rights and Realities, University of Nottingham, 30 November 1996. ם

\section{From Being Uprooted to Surviving: Resettlement of Vietnamese-Chinese "Boat People" in Montreal, $1980-1990$ By Lawreace Lam}

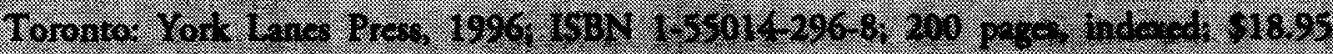

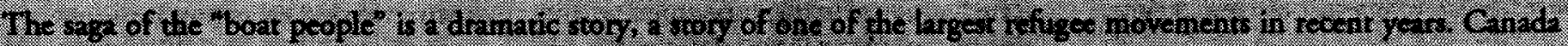

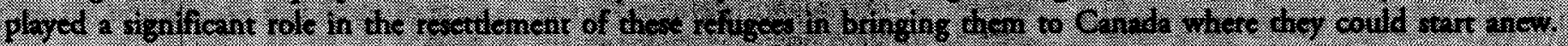

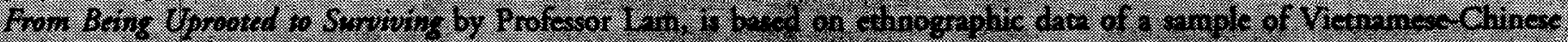

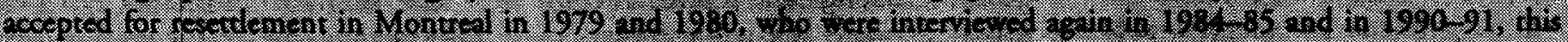

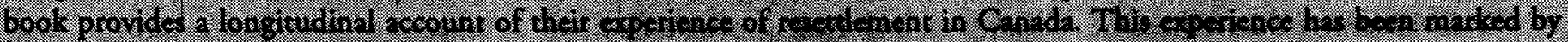

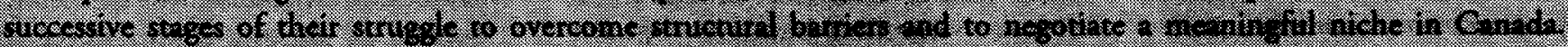

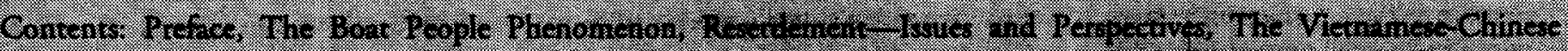

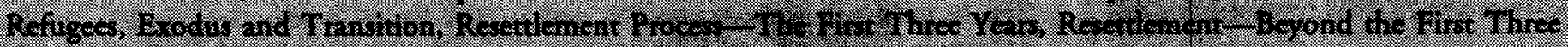

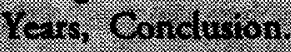

(C) Daniel Warner, 1998. This open-access work is licensed under a Creative Commons Attribution-NonCommercial 4.0 International License, which permits use, reproduction and distribution in any medium for non-commercial purposes, provided the original author(s) are credited and the original publication in Refuge: Canada's Journal on Refugees is cited. 